\section{The Effect of Growth Medium Temperature on Corn Salad [Valerianella locusta (L.) Laterr] Baby Leaf Yield and Quality}

\author{
Luisa Dalla Costa, Nicola Tomasi ${ }^{1}$, Stefano Gottardi, \\ and Francesco Iacuzzo \\ Dip. Scienze Agrarie e Ambientali, University of Udine, 33100 Udine, Italy
}

Giovanni Cortella

Dip. Ingegneria Elettrica, Gestionale e Meccanica, University of Udine, 33100 Udine, Italy

\section{Lara Manzocco}

Dip. Scienze degli Alimenti, University of Udine, 33100 Udine, Italy

Roberto Pinton

Dip. Scienze Agrarie e Ambientali, University of Udine, 33100 Udine, Italy

Tanja Mimmo and Stefano Cesco

Faculty of Science and Technology, Free University of Bozen, Bolzano, 39100 Bolzano, Italy

Additional index words. temperature, mineral nutrition, floating system, nitrate, yield, food quality

Abstract. Soil temperature has a crucial impact on physiological processes and growth of plants with important consequences for plant productivity and food safety including nitrate accumulation in leaf blades of leaf vegetables. Consumer demand for high-quality, fresh-cut vegetables has increased rapidly in the last decades, and temperature modulation can help control nitrate concentration in fresh vegetables, an important trait of product safety. Corn salad plants [Valerianella locusta (L.) Laterr., cultivar Gala] were grown at three root temperatures $\left(15,20\right.$, and $\left.25^{\circ} \mathrm{C}\right)$ in a floating system. This experimental setup allowed to directly evaluate the effect of root temperature on yield and plant quality excluding the effect on soil processes and properties. Nutrient solution was renewed weekly and kept aerated while air temperature was maintained constant at $20^{\circ} \mathrm{C}$ for all treatments during the entire time of experiments. At harvest, plants were collected, the shelf life evaluated, and the nutrient uptake $\left[\mathrm{NO}_{3}{ }^{-}\right.$, iron (Fe) from ${ }^{59} \mathrm{Fe}-0,0 \mathrm{EDDHA}$, and $\left.{ }^{35} \mathrm{SO}_{4}{ }^{2-}\right]$ and mineral content were determined. Results showed that growing conditions at $20^{\circ} \mathrm{C}$ of the nutrient solution led to the best plant performance in terms of yield, nitrate content at leaf level, root biomass, leaf area, and greenness with positive effects on postharvest quality, i.e., less rapid leaf loss of greenness and leaf fresh weight (FW) loss during conservation at $4{ }^{\circ} \mathrm{C}$. At this temperature condition of the nutrient solution, it has also been observed an enhanced functionality of mechanisms involved in the acquisition of nutrients like $\mathrm{NO}_{3}^{-}, \mathrm{Fe}$, and $\mathrm{SO}_{4}{ }^{2-}$, which are known to play an important role in nitrate level in leaf tissues of crops. Plants grown at $15^{\circ} \mathrm{C}$ showed minor growth, whereas the nutrient solution at $25^{\circ} \mathrm{C}$ caused stress for the plants affecting negatively the quality and yield. Overall, the results obtained showed that root temperature plays a fundamental role in several plant processes that affect yield and its quality; for hydroponic system cultivations, a level of growing-medium temperature close to that of the surrounding air seems suitable.

Received for publication 12 Sept. 2011. Accepted for publication 28 Oct. 2011.

This research was supported by a grant from "Ager-Agroalimentare e Ricerca" Foundation, project "Novel strategies meeting the needs of the fresh-cut vegetable sector-STAYFRESH; no. 2010 2370."

We are grateful to Prof Giorgio Gianquinto Prosdocimi, University of Bologna, and Dr. Kerr Walker, Scottish Agricultural College, for their helpful revision of the manuscript and constructive criticisms of four anonymous reviewers.

${ }^{1}$ To whom reprint requests should be addressed; e-mailnicola.tomasi@uniud.it.
It is well known that soil temperature changes have a significant impact on the growth and development of plants both in agricultural and native ecosystems (Bonan, 1992). During plant growth, optimum temperature is required below- and aboveground to ensure that plant development is not impaired (Summerfield et al., 1989). In recent years, much research activity has been devoted to assess the effect of temperature on plant growth and overall productivity. In the case of the soil component, when water is not limiting, soil nutrient availability generally increases with rising temperature as a result of faster chemical reactions that release nutrients from primary minerals, exchange sites of clay particles, and organic matter (Nxawe et al., 2010). With respect to the latter, temperature can either speed up or slow down the decomposition and mineralization processes of soil organic matter because these processes are closely related to the temperature-dependent metabolic activities of soil microbes (see review of Pregitzer et al., 2000). Consequently, temperature has a direct effect on nutrient availability at the root level with important impacts on the equilibrated development of plants and/or on the quality of the edible plant parts. In particular, in the case of nitrogen, high availability levels of nitrate may be the result of increased nitrogen mineralization induced by an increased soil temperature or the result of high fertilization rates. These issues have been widely considered as major causes of nitrate accumulation in leafy vegetable tissues leading to poorer quality products for human nutrition (Wang and Tadashi, 1997). In fact, although evidence about human health risk resulting from the recurrent and elevated nitrate intake is at the moment still under debate, it is widely accepted that lowering the dietary nitrate intake is an advisable preventive measure (Santamaria, 2006). For this reason, much effort is focused on reducing the content of this anion in edible plant tissues, because it is also a requirement of the European Community within EC Regulation $563 / 2002$. Recently it has been demonstrated that the higher accumulation of nitrate in edible tissues is not exclusively attributable to the anion availability in the growing medium; in fact, the availability of other nutrients could also play an important role in this phenomenon. For example, cucumber plants grown under Fe shortage accumulate high levels of nitrate at the leaf level (Nikolic et al., 2007) as well as spinach plants when the sulfur (S) availability in their growth medium is limited (Prosser et al., 2001). The unbalanced acquisition of these elements could be ascribed either to their low soil availability or by an impaired root capability to drive their acquisition, because it could occur when soil temperatures are inappropriate. In fact, considering what happens within the root component, it is well accepted that the mechanisms of soil-temperature effects on growth are complex and may include direct effects on growth and functions of roots such as nutrient uptake as well as indirect effects on shoot processes. Landhäusser et al. (2001) and Zhang and Dang (2007) demonstrated that low soil temperature is able to limit shoot growth and tends to increase the relative allocation of carbon $(\mathrm{C})$ to roots because nutrient and water uptake are reduced (Lambers et al., 1995; Leuschner et al., 2007). Rates of enzymatically driven root processes such as growth, nutrient uptake, and respiration may also be limited by low soil temperatures decreasing the demand of $\mathrm{C}$ and resulting in negative feedback of photosynthesis (Pregitzer et al., 2000; Thomas and Strain, 1991). Furthermore, it is well known that plants, to overcome 
changing of developmental and environmental demands on $\mathrm{C}$ and nitrogen $(\mathrm{N})$ resources, have evolved highly sophisticated and complex sensory systems that "crosstalk" to regulate $\mathrm{C}$ or $\mathrm{N}$ assimilation, metabolism, and transport (Coruzzi and Bush, 2001; Coruzzi and Zhou, 2001). For this reason, a small change in the soil temperature can have a profound impact on physiological processes and growth of plants (Clarkson et al., 1992; Moorby and Nye, 1984; Pregitzer and King 2005; Zhang and Dang, 2007) with serious consequences on food productivity and safety such as nitrate accumulation. So, it appears evident that the possibility of controlling the production process from the temperature point of view is extremely important and relevant considering also that consumer demand for high-quality, fresh-cut vegetables is increasing in the last decades (Brecht et al., 2004). However, for the processes occurring in the soil component, responses of roots to changes in soil temperature cannot be discriminated between those directly caused by biochemical and physiological processes and those related to simultaneous changes in soil properties like nutrient availability.

Information on the soil-temperature effects on root functionality appears of importance also for the soilless cultures in which the temperature of the nutrient solution can easily be modified by environmental conditions particularly in summer (heating) and in winter or early spring (cooling) periods. As for soil-grown plants, this can consistently affect several physiological functions (Nxawe et al., 2010) with undesired consequences on yield. The more this water-saving cultivation systems is being used (as happens in arid or semiarid regions such as the Mediterranean area where water, owing to its scarcity, costs, and quality is becoming an economically valuable resource), the more the knowledge of the effects of the growth-medium temperature on cultivated plants becomes relevant, particularly when yield could be hindered and/or its quality worsened.

For these reasons, the present work studied the effect of different temperatures of the growing medium on the production and quality of corn salad [Valerianella locusta (L.) Laterr., cultivar Gala] plants grown in soilless culture to exclude the effect of nutrient availability on the process. Functionality of mechanisms involved in $\mathrm{NO}_{3}{ }^{-}, \mathrm{SO}_{4}{ }^{2-}$, and $\mathrm{Fe}^{\mathrm{III}}$ acquisition has also been considered in relation to the levels of nitrate accumulated in the edible tissues.

\section{Material and Methods}

A flow chart summarizing the different treatments and analyses performed in this research is presented as Figure 1.

Plant material and growth conditions. Plants were grown hydroponically in a growth chamber as described by Iacuzzo et al. (2011) with the following controlled climatic conditions: day/night photoperiod, 16/8; radiation, $220 \mu \mathrm{E} \cdot \mathrm{m}^{-2} \cdot \mathrm{s}^{-1}$; air temperature (day/night) $20 \pm 0.9{ }^{\circ} \mathrm{C}$; relative humidity $70 \%$ to $80 \%$
(Cesco et al., 2006). Briefly, corn salad seeds [Valerianella locusta (L.) Laterr.; cultivar Gala from DOTTO SpA, Italy] were sown onto expanded polystyrene boards. After emergence, the boards were transferred into rectangular pots containing the aerated nutrient solution described by Manzocco et al. (2011). The nutrient solutions were renewed every week and aerated by bubbling to prevent anoxia and to guarantee the constant mixing of the solution.

Three sets of pots were used at three different temperatures of nutrient solution, 15, 20 , and $25^{\circ} \mathrm{C}$, and were named $\mathrm{T} 15, \mathrm{~T} 20$, and $\mathrm{T} 25$. These values of temperature were chosen considering the results of previous experiments performed in a greenhouse with plants grown both in soil and hydroponically, where the temperature of air, soil, and nutrient solution were monitored. These measurements showed significant daily temperature fluctuation in sunny weather (Fig. 2) with average values of temperature for soil and water in the range of 15 to $25^{\circ} \mathrm{C}$ depending on climatic conditions. Thus, in our experiments, the temperature of air in the growth chamber was set at the mentioned $20{ }^{\circ} \mathrm{C}$ values for all treatments during all time of the experiments and that of the nutrient solutions at $\approx 15,20$, and $25^{\circ} \mathrm{C}$. Because the temperature of the solution at the middle temperature $\left(20^{\circ} \mathrm{C}\right)$ corresponded with that of ambient conditions, it was not controlled. The pots with the solution at 15 and $25^{\circ} \mathrm{C}$ were supplied with a pipe at the bottom, where cold $\left(14^{\circ} \mathrm{C}\right)$ or hot $\left(26^{\circ} \mathrm{C}\right)$ water circulated to maintain the solution at the correct temperature without any contamination. Cold and hot water were supplied by independent cooling and heating systems appositely designed and whose activation was controlled by the temperature of the solution. The temperature of the nutrient solution in all the pots as well as of the air in the growth chamber was measured by several

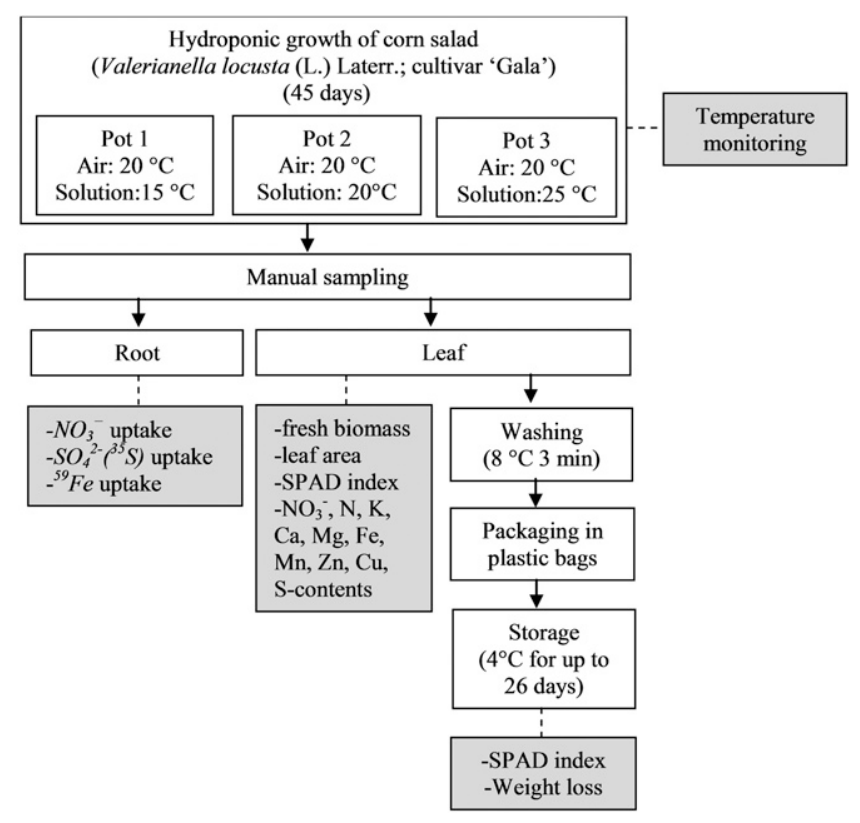

Fig. 1. Schematic representation of sample preparation (white boxes) and analytical determinations (gray boxes).

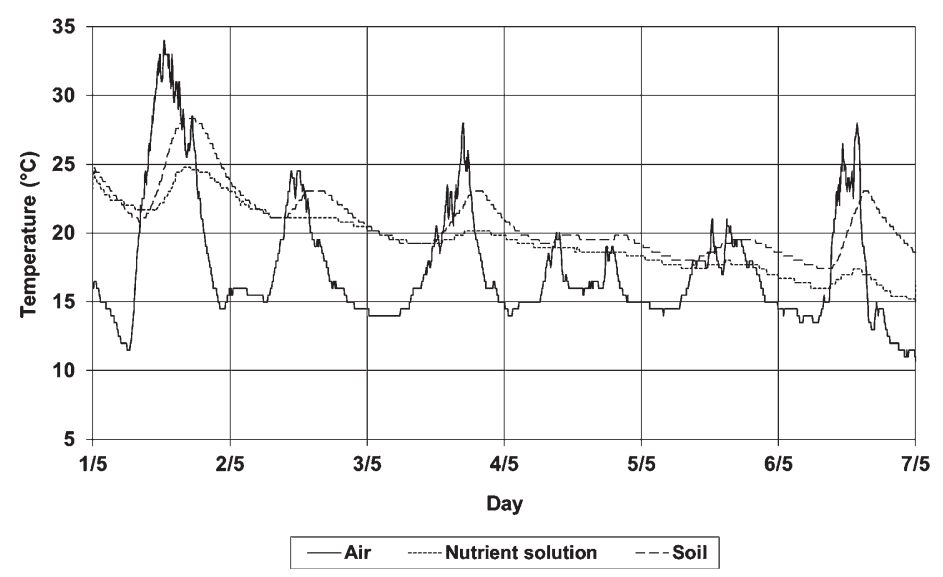

Fig. 2. Temperature profiles of air, nutrient solution, and soil in a typical week of May during the growing period of corn salad plants in the greenhouse. 
thermocouples " $\mathrm{T}$ " and a data acquisition unit (Agilent Technologies Italia S.p.A., Cernusco, Italy) at time intervals of 5 min during the entire experiment. The temperature values of the nutrient solution as recorded during the experiment were $15.2 \pm 0.2{ }^{\circ} \mathrm{C}, 19.8 \pm 0.6^{\circ} \mathrm{C}$, and $24.7 \pm 0.4{ }^{\circ} \mathrm{C}$.

Sampling. At the end of the growing period in hydroponics $(45 \mathrm{~d})$, the plants, with the exclusion of those at the board margins, were sampled, divided in root and shoot, and used for the analytical determinations and for the uptake assays.

SPAD and inductively coupled plasma measurements. Fresh biomass of plant tissues and leaf area, determined by using a LI-3100 Area Meter (LI-COR Inc., Lincoln, NE), are presented per square meter of floating board. SPAD index values of fully expanded young leaves were determined using a portable SPAD-502 m (Minolta, Osaka, Japan). Nutrient [phosphorus $(\mathrm{P}), \mathrm{S}$, potassium $(\mathrm{K})$, calcium $(\mathrm{Ca})$, magnesium $(\mathrm{Mg}), \mathrm{Fe}$, manganese $(\mathrm{Mn})$, zinc $(\mathrm{Zn})$, and copper $(\mathrm{Cu})]$ contents in leaf tissues were determined, after their digestion with $\mathrm{H}_{2} \mathrm{O}_{2}$, as follows: inorganic $\mathrm{P}$ was quantified spectrophotometrically at $705 \mathrm{~nm}$ as described by Forbush (1983); K, $\mathrm{Ca}, \mathrm{Mg}, \mathrm{Fe}, \mathrm{Mn}, \mathrm{Zn}$, and $\mathrm{Cu}$ contents were analyzed by inductively coupled plasma atomic emission spectrometry (VISTA MPX; Varian, Torino, Italy) as described by Zuchi et al. (2009). To determine total S concentration, according to Astolfi et al. (2006), dried leaf samples were ashed in a muffle furnace at $600{ }^{\circ} \mathrm{C}$; the ashes were dissolved in $10 \mathrm{~mL}$ of $3 \mathrm{M} \mathrm{HCl}$ and filtered through Whatman No. 42 paper. In contact with $\mathrm{BaCl}_{2}, \mathrm{BaSO}_{4}$ precipitate is formed, which is determined turbidimetrically.

Washing, packaging, and storage. At harvest, shoot samples were collected and quickly washed with distilled water at $8{ }^{\circ} \mathrm{C}$ for $3 \mathrm{~min}$. The salad/water ratio during washing was 1:18 w/w. Aliquots of $50 \mathrm{~g}$ of corn salad were packed under air in $30 \times 40-\mathrm{cm}$ plastic bags. Samples were stored in the dark at $4{ }^{\circ} \mathrm{C}$ for up to $26 \mathrm{~d}$. After $5,8,14,19$, and $26 \mathrm{~d}$ of storage, SPAD index value and weight loss $(\%)$ of packed corn salads were determined. Weight loss was assessed by weighing the content of the packages before and after the storage period. Weight loss was expressed as the percentage of weight loss with respect to initial weight.

Measurement of net $\mathrm{NO}_{3}^{-}$uptake by roots and determination of nitrogen and $\mathrm{NO}_{3}{ }_{3}$ contents in leaf tissues. Nitrate uptake by root was measured as described by Nikolic et al. (2007) using excised roots $(\approx 0.8 \mathrm{~g}$ of FW) of corn salad plants (45 days old) and an uptake solution $(20 \mathrm{~mL})$ containing $1 \mathrm{~mm}$ $\mathrm{KNO}_{3}$. To evaluate the functionality of the mechanisms involved in the acquisition process of the nutrient at the growing conditions, uptake medium was maintained at the temperature of 15,20 , or $25^{\circ} \mathrm{C}$ for the root tissues of plants grown at 15,20 , or $25^{\circ} \mathrm{C}$, respectively. The $\mathrm{NO}_{3}{ }^{-}$depletion from the uptake solution was measured over $10 \mathrm{~min}$ by removing every $2 \mathrm{~min} 0.2-\mathrm{mL}$ aliquots and the concentration of $\mathrm{NO}_{3}{ }^{-}$determined spectrophotometrically. The net $\mathrm{NO}_{3}{ }^{-}$uptake rate was calculated by linear regression analysis and expressed as $\mu \mathrm{mol} \mathrm{NO}_{3}-\mathrm{g}$ dry weight (DW) of root per hour. Cell juices of leaf samples were prepared by thawing the leaf tissues followed by centrifugation at $10,000 \mathrm{~g}$ for $15 \mathrm{~min}$. The concentration of $\mathrm{NO}_{3}{ }^{-}$in leaf samples was determined spectrophotometrically. Total $\mathrm{N}$ has been also measured in these tissues using a $\mathrm{CHN}$ analyser.

Measurements of $\mathrm{SO}_{4}{ }^{2-}\left({ }^{35} \mathrm{~S}\right)$ uptake. The capability of the root to acquire ${ }^{35} \mathrm{SO}_{4}{ }^{2-}$ was assessed as described by Astolfi et al. (2006) with slight modifications. Briefly, excised root sampled as previously described were washed with water. After $30 \mathrm{~min}$, roots were transferred to beakers containing $20 \mathrm{~mL}$ of a freshly prepared micronutrient- and $\mathrm{SO}_{4}{ }^{2-}$ free uptake solution. Sulphate $\left({ }^{35} \mathrm{SO}_{4}{ }^{2-}\right.$, specific activity $2.1 \mathrm{KBq} \mu \mathrm{mol}^{-1}{ }^{35} \mathrm{SO}_{4}{ }^{2-}$ ) was added at a $0.6 \mathrm{~mm}$ concentration and the uptake period was $30 \mathrm{~min}$. To evaluate the functionality at the growing conditions (temperature of 15,20 , or $25{ }^{\circ} \mathrm{C}$ of growing medium) of the mechanisms involved in the acquisition process of the nutrient, uptake medium was maintained at the temperature of 15,20 , or $25^{\circ} \mathrm{C}$. Thereafter, the root tissues were transferred to an ice-cold desorption solution containing $0.6 \mathrm{mM} \mathrm{CaSO}_{4}$ and $10 \mathrm{~mm}$ MES [2-(N-morpholino)ethanesulfonic acid]$\mathrm{KOH}$ ( $\mathrm{pH} 6.0$ ) for $30 \mathrm{~min}$. Roots were ovendried at $60{ }^{\circ} \mathrm{C}$, weighed, mineralized with $10 \% \mathrm{H}_{2} \mathrm{O}_{2}$ at $60{ }^{\circ} \mathrm{C}$, and suspended in $1 \mathrm{M} \mathrm{HCl}$ for ${ }^{35} \mathrm{SO}_{4}{ }^{2-}$ determination by liquid scintillation counting. The ${ }^{35} \mathrm{SO}_{4}{ }^{2-}$ uptake rate is presented in $\mu \mathrm{mol} \mathrm{SO}{ }_{4}{ }^{2-} / \mathrm{g} \mathrm{DW}$ of root per hour.

Measurements of ${ }^{59} \mathrm{Fe}$ uptake from $\mathrm{Fe}$-o, oEDDHA. The capability of the root to acquire ${ }^{59} \mathrm{Fe}$ from ${ }^{59} \mathrm{Fe}$ (III)-o,oEDDHA was assessed as described by Cesco et al. (2002) with slight modifications. To achieve this, excised roots were washed with $\mathrm{CaSO}_{4} 0.5 \mathrm{~mm}$ for 30 min and then transferred to beakers containing $20 \mathrm{~mL}$ of a freshly prepared micronutrientfree uptake solution having the following composition (mM): $\mathrm{K}_{2} \mathrm{SO}_{4} 0.7, \mathrm{KCl} 0.1, \mathrm{Ca}\left(\mathrm{NO}_{3}\right)_{2}$ 2.0, $\mathrm{MgSO}_{4}$ 0.5, $\mathrm{KH}_{2} \mathrm{PO}_{4}$ 0.1, MES-KOH 10 ( $\mathrm{pH}$ 6.0). Iron- $\left({ }^{59} \mathrm{Fe}\right)-\mathrm{o}, \mathrm{oEDDHA}$, prepared by mixing ${ }^{59} \mathrm{FeCl}_{3}$ with EDDHA with a molar ratio of $1: 1.1$ (specific activity of $114 \mathrm{KBq}$ $\mu_{\mathrm{mol}}{ }^{-1} \mathrm{Fe}$; Rodríguez-Lucena et al., 2009) was added to give a final $\mathrm{Fe}$ concentration of

Table 1. Effect of temperature on leaf yield and area of corn salad [Valerianella locusta (L.) Laterr., cultivar Gala] grown for $45 \mathrm{~d}$ in nutrient solution maintained at a constant temperature of 15,20 , or $25^{\circ} \mathrm{C} .{ }^{\mathrm{z}}$

\begin{tabular}{lccc}
\hline & \multicolumn{3}{c}{ Nutrient solution temp. $\left({ }^{\circ} \mathrm{C}\right)$} \\
\cline { 2 - 4 } & 15 & 20 & 25 \\
\hline Leaf yield $\left(\mathrm{g} \mathrm{FW} / \mathrm{m}^{2}\right)$ & $1264 \pm 91 \mathrm{~B}$ & $1560 \pm 185 \mathrm{~A}$ & $897 \pm 129 \mathrm{C}$ \\
Leaf area $\left(\mathrm{m}^{2} \cdot \mathrm{m}^{-2}\right)$ & $4.11 \pm 0.19 \mathrm{~A}$ & $3.84 \pm 0.44 \mathrm{~A}$ & $4.34 \pm 0.38 \mathrm{~A}$ \\
Number of leaves (no. per plant) & $6.6 \pm 0.4 \mathrm{~B}$ & $7.7 \pm 0.6 \mathrm{~A}$ & $5.9 \pm 0.8 \mathrm{~B}$ \\
SPAD index & $37.5 \pm 1.0 \mathrm{~A}$ & $38.9 \pm 0.9 \mathrm{~A}$ & $34.9 \pm 1.2 \mathrm{~B}$ \\
Dry weight percentage & $6.7 \pm 0.2 \mathrm{C}$ & $7.8 \pm 0.2 \mathrm{~B}$ & $8.2 \pm 0.1 \mathrm{~A}$ \\
$\mathrm{NO}_{3}{ }^{-}\left(\mathrm{g} \cdot \mathrm{kg}^{-1}\right.$ leaf $\left.\mathrm{FW}\right)$ & $4.46 \pm 0.21 \mathrm{~A}$ & $3.94 \pm 0.08 \mathrm{~B}$ & $4.11 \pm 0.09 \mathrm{~B}$ \\
\hline
\end{tabular}

${ }^{\mathrm{z}}$ Air temperature has been maintained constant at a value of $20{ }^{\circ} \mathrm{C}$ for the entire experiment. Data of number of leaves per plant, SPAD index values, DW/FW ratios, and nitrate contents are also reported. Data are means \pm SD of three independent experiments; capital letters refer to statistically significant differences among the samples (analysis of variance, Fisher's least significant difference, $P<0.05$ ).

$\mathrm{FW}=$ fresh weight; DW = dry weight.
$100 \mu \mathrm{M}$. To limit photochemical reduction of the micronutrient in the uptake solution added by the Fe source (Hernández-Apaolaza and Lucena, 2011; Zancan et al., 2006), beakers we plastic foils during buffered at pH 6.0 with $10 \mathrm{~mm}$ MES-KOH and the uptake period was $30 \mathrm{~min}$. To evaluate the functionality of the mechanisms involved in the acquisition process of the nutrient at the growing conditions (temperature of 15,20 , or $25{ }^{\circ} \mathrm{C}$ of the growing medium), uptake medium was maintained at a temperature of 15 , 20 , or $25^{\circ} \mathrm{C}$. Thereafter, plants were transferred to a freshly prepared ${ }^{59} \mathrm{Fe}$-free nutrient solution for $10 \mathrm{~min}$ to remove the excess of ${ }^{59} \mathrm{Fe}$ at the root surface and then harvested. 1.2 . L $^{-1}$ sodic ${ }^{\circ}$ Fe pools were removed by bipyridyl in $1 \mathrm{~mm} \mathrm{Ca}\left(\mathrm{NO}_{3}\right)_{2}$ under bubbling $\mathrm{N}_{2}$. Root tissues were oven-dried at $80{ }^{\circ} \mathrm{C}$, weighed, ashed at $550{ }^{\circ} \mathrm{C}$, and suspended in $1 \mathrm{M} \mathrm{HCl}$ for ${ }^{59} \mathrm{Fe}$ determination by liquid scintillation counting. The ${ }^{59} \mathrm{Fe}$ uptake rate, measured as $\mu \mathrm{mol}{ }^{59} \mathrm{Fe}$, refers to the whole root tissues and is presented per $\mathrm{g} / \mathrm{DW}$ of oots per hour.

Statistical analysis. Each experiment was repeated three times in climate chamber over a period of 2 years and the significance of culated using the analysis of variance analyses (Fisher's least significant difference) with SigmaPlot (Version 11; Systat Software, Evanston, IL).

\section{Results}

Plants were able to accumulate the highest values of fresh leaf biomass $(1560 \pm 185 \mathrm{~g}$ $\mathrm{m} / \mathrm{m}^{2}$ ) when grown at the constant temperperature (T15) led to a significant decrease of yield (fresh biomass) and a warming of the solution by $5{ }^{\circ} \mathrm{C}$ (T25) severely limited not attributable to leaf thickness, because leaf specific weight, indicated by leaf area per gram, did not show any significant difference among the three treatments. Number and size of leaf components were responsible for the overall difference in yield. Focusing on the A $5{ }^{\circ} \mathrm{C}$ decrease in the nutrient solution temductivity among the three temperatures was 
number of leaves, plants grown T20 had significantly higher numbers of leaves than those obtained in T15 and T25; plants grown at lower temperature (T15) exhibited yield restriction with respect to those grown at $20{ }^{\circ} \mathrm{C}$ with a restrain value smaller than that observed in T25. As shown in Table 1, leaves were progressively less hydrated as temperature increased. In fact, the DW percentage of leaves was significantly higher in leaf blades of plants grown in T25, reporting the lowest water content. Significantly higher hydration values were observed in plants of T20 and $\mathrm{T} 15$. Corn salad leaves grown in $\mathrm{T} 15$ and $\mathrm{T} 20$ presented similar chlorophyll contents as measured with the SPAD index value. However, this parameter was significantly lower when salad was grown in T25, indicating lower greenness of the leaves. Concerning $\mathrm{NO}_{3}^{-}$concentration in leaf tissues, no significant differences could be observed between T25 and T20, whereas a significant increase in $\mathrm{NO}_{3}{ }^{-}$concentration was detected in plants grown in T15 (Table 1). Figure 3 shows the amount of $\mathrm{N}$ accumulated by leaves of plant; data are expressed as grams per square meter of floating boards. When plants were grown at $20^{\circ} \mathrm{C}$, the highest accumulation of $\mathrm{N}$ has been recorded; on the contrary, the lowest level of $\mathrm{N}$ was measured in plants exposed to $25{ }^{\circ} \mathrm{C}$. Nitrate forms represent approximately one-fourth of the total amount, exhibiting the lowest ratio in plant grown at $20^{\circ} \mathrm{C}$. Leaf nutrient concentrations at harvest are reported in Table 2. Higher concentration values of $\mathrm{P}, \mathrm{S}, \mathrm{Zn}$, and $\mathrm{Cu}$ were observed in leaf tissues of T25 plants with respect to those measured when the nutrient solution was maintained at $20{ }^{\circ} \mathrm{C}$; conversely, T15 plants exhibited a higher accumulation of $\mathrm{K}$ and $\mathrm{Mg}$ (Table 2).

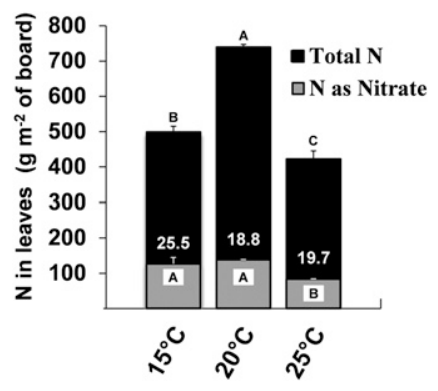

Fig. 3. Effect of the nutrient solution temperature on nitrogen $(\mathrm{N})$ accumulation in leaves of corn salad [Valerianella locusta (L.) Laterr., cultivar Gala] grown for $45 \mathrm{~d}$ in nutrient solution maintained at a constant temperature of 15 , 20 , or $25^{\circ} \mathrm{C}$. Air temperature has been maintained constant at a value of $20{ }^{\circ} \mathrm{C}$ for the entire experiment. Data, expressed as per square meter of cultivation board, are referred to total $\mathrm{N}$ accumulation (black box) and $\mathrm{N}$ accumulated as nitrate (shaded box); ratios (\%) between $\mathrm{N}$ as nitrate and total $\mathrm{N}$ are also reported. Data are means \pm SD of three independent experiments; capital letters refer to statistically significant differences among the samples (analysis of variance, Fisher's least significant difference, $P<0.05$ ).
Figure 4A points out the effects of the three levels of temperature on root biomass. When corn salad plants were grown in nutrient solution maintained at $20^{\circ} \mathrm{C}$, they were able to develop a root system of $89 \mathrm{~g} \mathrm{FW} / \mathrm{m}^{2}$. A cooling of the nutrient solution to reach the constant value of $15{ }^{\circ} \mathrm{C}$ led the plants to accumulate a greater, but not significant, root biomass, whereas warming of the hydroponic solution at $25^{\circ} \mathrm{C}$ significantly limited the root yield. Considering the leaf yield at harvest, when plants were grown at $\mathrm{T} 15$, a ratio between root and leaf fresh biomass greater than those measured for plants treated at the other two temperatures was recorded (Fig. 4B).

To evaluate the functionality of $\mathrm{NO}_{3}{ }^{-}$, $\mathrm{Fe}(\mathrm{III})$-chelate, and $\mathrm{SO}_{4}{ }^{2-}$ acquisition mechanisms operating at the root level of corn salad plants grown at three levels of temperature of the nutrient solution, uptakes of $\mathrm{NO}_{3}{ }^{-}$, Fe from ${ }^{59} \mathrm{Fe}(\mathrm{III})-\mathrm{o}, \mathrm{oEDDHA}$, and ${ }^{35} \mathrm{SO}_{4}{ }^{2-}$ (Table 3) were measured using excised roots from plants at the harvested stage and maintaining the temperature values of uptake media corresponding to those of the nutrient solutions. As shown in Table 3, the rise in temperature from 15 to $20^{\circ} \mathrm{C}$ induced a clear increase in nutrient acquisition capability of $\mathrm{NO}_{3}{ }^{-}(+81 \%),{ }^{35} \mathrm{SO}_{4}{ }^{2-}(+16 \%)$, and $\mathrm{Fe}(+15 \%)$. Conversely, a further warming of root temperature (T25) caused a drastic limitation of $\mathrm{NO}_{3}{ }^{-}$and $\mathrm{SO}_{4}{ }^{2-}$ acquisition, halving their uptake rates. Similarly, a remarkable reduction was recorded for Fe uptake when the temperature of the nutrient solution was maintained at $25^{\circ} \mathrm{C}$.

The effect of the growth medium temperature was also evaluated in the post-harvest period measuring both the SPAD index and the weight loss of corn salad packed under air and stored up to $25 \mathrm{~d}$ at $4{ }^{\circ} \mathrm{C}$. Temperature of the nutrient solution influenced SPAD index during post-harvest storage; bleaching of the leaves was found to proceed slower as the temperature of the nutrient solution was increased (Fig. 5A). The loss of weight from leaf blade dehydration appeared particularly fast during storage of leaves collected from T15 plants (Fig. 5B).

\section{Discussion}

Among all the environmental parameters, temperature is considered the most able to affect plant growth and some authors (Gavito et al., 2001) have suggested to consider air and soil temperatures in studies of plant growth with the same relevance of soil fertility. Concerning its effects, it is well known that soil temperature can strongly influence plant growth acting indirectly on soil properties (such as nutrient availability) or directly on the biochemical and physiological processes of the whole plant (such as nutrient acquisition and metabolism). Following this, plant yield may be affected considerably by this parameter with, in some cases, consequences on safety such as nitrate content in edible leaf tissues (Lawlor et al., 1987a, 1987b, 1988; Miller et al., 2001; Santamaria, 2006). However, when this aspect is studied using soil-grown plants, discriminating the relative contribution between these two components appears very difficult; furthermore, the identification of possible solutions to the problem is not so easy, particularly when addressing the critical aspects of root components. For these reasons, in the present work, the effect of temperature of the growing medium on yield and quality of ready-to-eat corn salad plants has been evaluated using a soilless system, in which the availability of nutrients was maintained at its optimal values; furthermore, in silico analyses with a geochemical model excluded any effect of the three values of temperature $\left(15,20\right.$, or $\left.25^{\circ} \mathrm{C}\right)$ on the chemical equilibria and the availability of the dissolved nutrients (data not shown). Then, with this approach, it was possible to evaluate the direct effects of hydroponic solution temperature on yield and quality of the edible tissues taking into account physiological processes related to these aspects such as nutrient acquisition but excluding the effect of soil processes and properties.

Results of this study showed that when corn salad plants were grown in a nutrient solution maintained at the temperature of $20^{\circ} \mathrm{C}$ (T20), edible yield (leaf biomass; Table 1) was higher than that observed in plants exposed to $15{ }^{\circ} \mathrm{C}$ (T15) for the entire time of the experiment. Furthermore, the greenness of these leaves (T20) was more intense; this is an interesting aspect because consumers mainly judge the acceptability of ready-to-eat vegetables based on their appearance. Similarly, higher yield and more evident greening with temperature rise have also been described

Table 2. Effect of the nutrient solution temperature on cationic nutrients in leaf samples of corn salad [Valerianella locusta (L.) Laterr., cultivar Gala] grown as described in Table $1 .^{z}$

\begin{tabular}{lrrr}
\hline & \multicolumn{3}{c}{ Nutrient solution temp. $\left({ }^{\circ} \mathrm{C}\right)$} \\
\cline { 2 - 4 } & \multicolumn{1}{c}{15} & \multicolumn{1}{c}{20} & 25 \\
\hline Phosphorus $\left(\mathrm{g} \cdot \mathrm{kg}^{-1}\right.$ leaf DW) & $25.5 \pm 6.2 \mathrm{~B}$ & $22.2 \pm 0.8 \mathrm{~B}$ & $33.8 \pm 3.4 \mathrm{~A}$ \\
Sulfur $\left(\mathrm{g} \cdot \mathrm{kg}^{-1}\right.$ leaf DW) & $16.9 \pm 1.8 \mathrm{~B}$ & $13.3 \pm 1.4 \mathrm{C}$ & $30.2 \pm 1.6 \mathrm{~A}$ \\
Potassium $\left(\mathrm{g} \cdot \mathrm{kg}^{-1}\right.$ leaf DW) & $22.3 \pm 4.8 \mathrm{~A}$ & $15.6 \pm 1.2 \mathrm{~A}$ & $19.2 \pm 1.7 \mathrm{~A}$ \\
Calcium $\left(\mathrm{g} \cdot \mathrm{kg}^{-1}\right.$ leaf DW) & $1.7 \pm 0.5 \mathrm{~A}$ & $1.7 \pm 0.1 \mathrm{~A}$ & $1.3 \pm 0.1 \mathrm{~A}$ \\
Magnesium $\left(\mathrm{g} \cdot \mathrm{kg}^{-1}\right.$ leaf DW) & $0.8 \pm 0.1 \mathrm{~A}$ & $0.6 \pm 0.1 \mathrm{~A}$ & $0.7 \pm 0.1 \mathrm{~A}$ \\
Iron $\left(\mathrm{mg} \cdot \mathrm{kg}^{-1}\right.$ leaf DW) & $65.6 \pm 8.6 \mathrm{AB}$ & $81.3 \pm 9.7 \mathrm{~A}$ & $55.8 \pm 8.8 \mathrm{~B}$ \\
Manganese $\left(\mathrm{mg} \cdot \mathrm{kg}^{-1}\right.$ leaf DW) & $20.8 \pm 3.5 \mathrm{~B}$ & $51.0 \pm 0.5 \mathrm{~A}$ & $46.4 \pm 5.7 \mathrm{~A}$ \\
Zinc $\left(\mathrm{mg} \cdot \mathrm{kg}^{-1}\right.$ leaf DW) & $30.8 \pm 13.1 \mathrm{AB}$ & $16.7 \pm 0.6 \mathrm{~B}$ & $41.9 \pm 2.7 \mathrm{~A}$ \\
Copper $\left(\mathrm{mg}^{\mathrm{kg}} \mathrm{kg}^{-1}\right.$ leaf DW) & $1.8 \pm 0.2 \mathrm{~B}$ & $0.8 \pm 0.1 \mathrm{C}$ & $3.6 \pm 0.7 \mathrm{~A}$ \\
\hline
\end{tabular}

${ }^{z}$ Data are means \pm SD of three independent experiments; capital letters refer to statistically significant differences among the samples (analysis of variance, Fisher's least significant difference, $P<0.05$ ). DW $=$ dry weight. 
A

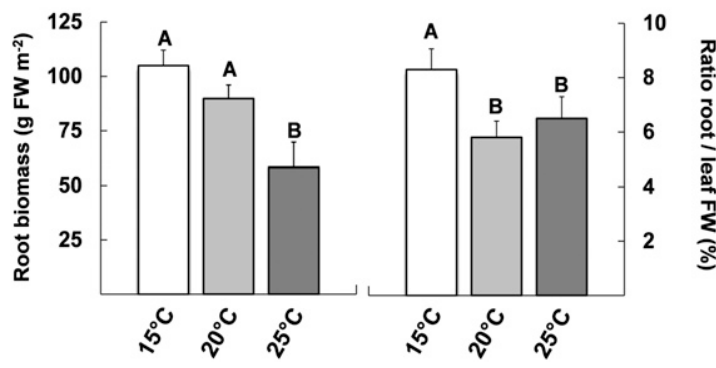

Fig. 4. Effect of the nutrient solution temperature on root biomass of corn salad [Valerianella locusta (L.) Laterr., cultivar Gala] grown as described in Figure 3. Data of root biomass (A) and root FW/leaf FW ratios (B) are reported. Data are means \pm SD of three independent experiments; capital letters refer to statistically significant differences among the samples (analysis of variance, Fisher's least significant difference, $P<0.05)$. FW $=$ fresh weight.

Table 3. Effect of the nutrient solution temperature on $\mathrm{NO}_{3}^{-}, \mathrm{SO}_{4}{ }^{2-}$, and $\mathrm{Fe}^{\mathrm{III}}$ uptake by roots of corn salad [Valerianella locusta (L.) Laterr., cultivar Gala] grown as described in Table 1. ${ }^{\mathrm{z}}$

\begin{tabular}{|c|c|c|c|}
\hline & \multicolumn{3}{|c|}{ Nutrient solution temp. $\left({ }^{\circ} \mathrm{C}\right)$} \\
\hline & 15 & 20 & 25 \\
\hline $\mathrm{NO}_{3}{ }^{-}$uptake $\left(\mu \mathrm{mol} \cdot \mathrm{g}^{-1}\right.$ root $\left.\mathrm{DW} / \mathrm{h}\right)$ & $173 \pm 31 \mathrm{~B}$ & $313 \pm 15 \mathrm{~A}$ & $115 \pm 23 \mathrm{C}$ \\
\hline${ }^{35} \mathrm{SO}_{4}{ }^{2-}$ uptake $\left(\mu \mathrm{mol} \cdot \mathrm{g}^{-1}\right.$ root $\left.\mathrm{DW} / \mathrm{h}\right)$ & $70.1 \pm 5.4 \mathrm{~B}$ & $81.2 \pm 2.9 \mathrm{~A}$ & $35.4 \pm 5.8 \mathrm{C}$ \\
\hline${ }^{59} \mathrm{Fe}^{\mathrm{III}}$ uptake $\left(\mu \mathrm{mol} \cdot \mathrm{g}^{-1}\right.$ root DW/h) & $0.89 \pm 0.08 \mathrm{~B}$ & $1.02 \pm 0.06 \mathrm{~A}$ & $0.56 \pm 0.03 \mathrm{C}$ \\
\hline \multicolumn{4}{|c|}{$\begin{array}{l}\mathrm{Fe}^{\mathrm{z} N \mathrm{III}} \text { or } \mathrm{SO}_{4}{ }^{2-} \text { uptake were determined at } \mathrm{pH} 6.0 \text { by using }{ }^{59} \mathrm{Fe}(\mathrm{Fe}-\mathrm{o}, \mathrm{oEDDHA} \text {, final iron concentration of } 100 \\
\mu \mathrm{M}) \text { or }{ }^{35} \mathrm{~S}\left(\mathrm{SO}_{4}{ }^{2-} \text {, final sulfur concentration of } 600 \mu \mathrm{mol} \mathrm{L} \mathrm{L}^{-1}\right) \text { tracers, respectively. Temperatures of the } \\
\text { uptake media were maintained at the same levels of those used in the growing conditions. Data are means } \pm \\
\text { sD of three independent experiments; capital letters refer to statistically significant differences among the } \\
\text { samples (analysis of variance, Fisher's least significant difference, } P<0.05) \text {. } \\
\text { DW = dry weight. }\end{array}$} \\
\hline
\end{tabular}
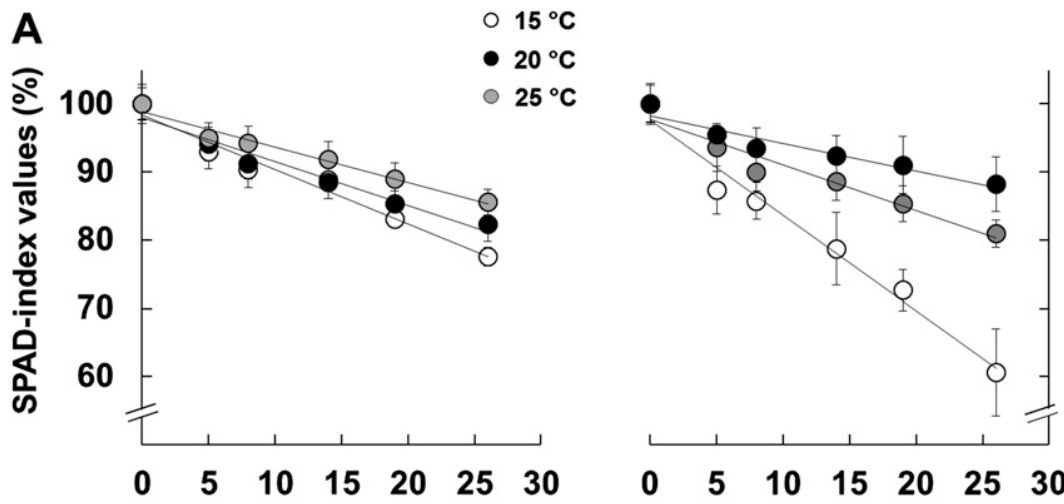

\section{Time after the harvest (d)}

Fig. 5. Effect of the nutrient solution temperature on SPAD index values and weight loss (\%) during postharvest storage at $4{ }^{\circ} \mathrm{C}$ of corn salad leaves [Valerianella locusta (L.) Laterr., cultivar Gala] grown as described in Figure 3. Data are means \pm SD of three independent experiments.

for other soilless production systems (Nxawe et al., 2009), particularly in the early spring period when plant growth is strongly dependent on temperature (Westwood, 1988). Changing temperature of the nutrient solution from 15 to $20{ }^{\circ} \mathrm{C}$ increased also the nutrient uptake rates of $\mathrm{NO}_{3}^{-}, \mathrm{Fe}$, and $\mathrm{SO}_{4}{ }^{2-}$ (Table 2), which in turn might have speeded up metabolic processes and hence shoot growth (Dong et al., 2001; Ndakidemi and Semoka, 2006). Concerning nitrate uptake, its increased rate at T20 is concomitant with a smaller nitrate accumulation at the leaf level (Table 1); although it seems contradictory, it is well demonstrated that under abiotic stress, like nutrient deficiencies, plants accumulate nitrate in leaves even if the uptake rate of the nitrate anion is depressed (Iacuzzo et al., 2011; Nikolic et al., 2007; Prosser et al., 2001). As argued by these authors, the nitrate accumulation is mainly the result of slower growth and a comparatively higher repression of the assimilation process than the uptake one. In fact, when the ratios between $\mathrm{N}$ as nitrate and total $\mathrm{N}$ accumulated at the leaf level are considered (Fig. 3), it appears evident that an enhanced nitrate assimilation process occurred in plants maintained in a growth medium and air temperature of $20{ }^{\circ} \mathrm{C}$. Furthermore, it is interesting to note that the uptake rates of all the three nutrients were enhanced with the temperature rise indicating how an equilibrate growth of plants requires a balanced acquisition of the three elements (Iacuzzo et al., 2011). The observed changes in nutrient uptake capability, as also observed in previous work on ammonium, $\mathrm{P}$, and $\mathrm{K}$ (see the review of Bassirirad, 2000), can be at least partially explained by the effect of temperature on root respiration, a temperature-sensitive process that mediates ion movement across the root. However, because ion uptake is not the only root function that requires energy from respiration, despite the tight linkage between root nutrient uptake and respiration, it should not be assumed that increased soil temperature would affect root nutrient uptake as a linear function of root respiration (Bassirirad, 2000). Dong et al. (2001) argued that nutrient uptake and root functions are simultaneously regulated by soil temperature. Furthermore, as reported by Buckley (2008), one general characteristic of plant growth is the strong relationship between structural development and physiological functioning of roots and shoots. For these reasons, the enhanced nutrient fluxes recorded at the root level could influence processes such as photosynthesis at the shoot level (Calatayud et al., 2004, 2008; Santarius, 2004; Yamori et al., 2006, 2008) exerting in turn pronounced effects on shoot growth and consequently on yield (Bowen, 1991). In addition, experimental evidence shows that, when plants are exposed to cold temperature, a following rising of temperature might modify the carbon allocation among roots and shoots (Lambers and Poorter, 1992) favoring the lower levels of biomass accumulation at the root level similar to that observed in this work by increasing the hydroponic solution temperature from 15 to $20^{\circ} \mathrm{C}$ (Fig. 4). Clarkson et al. (1988) suggested that the response of nutrient uptake to temperature might represent changes in plant nutrient demand per unit root and not an acclimatory change in root transport properties. Nonetheless, with the exception of $\mathrm{Fe}$ and $\mathrm{Mn}$, the considerably enhanced biomass production resulting from the warming of the nutrient solution from 15 to $20^{\circ} \mathrm{C}$ might have caused a dilution of nutrient concentrations of leaf tissues (Table 2). In particular, with respect to nitrate contents, which are an important aspect of food safety (Santamaria, 2006), the temperature rise could also either favor $\mathrm{NO}_{3}{ }^{-}$assimilation processes or limit the large storage capacity of plant tissues for $\mathrm{NO}_{3}{ }^{-}$in cells, a phenomenon observed when metabolism is restricted by low temperature (Lawlor, 2002). This aspect is also evident in leaf tissues of T20 plants as compared with those of T15 plants (Fig. 3), in which the ratio of nitrate- $\mathrm{N}$ on the total $\mathrm{N}$ is significantly lower. In addition to the low nitrate contents, it is interesting to note that the ready-to-eat corn salad from T20 plants showed a lower tendency to bleaching and dehydration during storage (Fig. 5) as compared with that obtained from T15 plants. Based on these 
results, it can be inferred that setting the temperature of the nutrient solution at $20{ }^{\circ} \mathrm{C}$ could be particularly effective in obtaining fresh-cut products with higher physical stability and hence longer shelf life.

When the temperature of the nutrient solution was raised to $25^{\circ} \mathrm{C}$, levels of edible yield (leaf biomass; Table 1) dropped to the lowest values of those recorded in the three treatments. Furthermore, these plants (T25) developed foliage with fewer leaves and with the lowest greenness intensity. These effects are in agreement with that observed when plants are exposed to high soil temperatures clearly indicating that the temperature of $25{ }^{\circ} \mathrm{C}$ for a nutrient solution represents too high a value for balanced and unstressed growth of corn salad plant. In fact, the characteristic limitation by high soil temperature of root growth (Xu and Huang, 2000), water content (Graves et al., 1991; Huang et al., 1991), nutrient uptake (Huang and Xu, 2000), and oxidative damage in leaves (Huang et al., 2001) was also evident in our T25 corn salad plants (Tables 1 and 3 ) indicating a sort of high-temperature stress for these plants. The leaves of these plants showed slower bleaching and weight loss (Fig. 5) during postharvest storage in comparison with the values observed in T15 plants. At harvest, the worst leaf quality of leaves in T25 plants (lower greenness and higher dry weight percentage; Table 1) could reasonably contribute to the slowed tendency to bleaching and dehydration of the leaves during storage (Fig. 5). Data reported in Table 1 show that, although root $\mathrm{NO}_{3}{ }^{-}$uptake was more than halved in $\mathrm{T} 25$, nitrate contents in theses leaves were slightly increased compared with T20. Lawlor (2002) argued that the rate of protein synthesis, central in $\mathrm{N}$ metabolism and plant growth, when all the other factors are not limiting, strongly depends on temperature; it stops at very low temperatures, increasing to a maximum as temperature rises before decreasing with further increase. This affects all plant processes thereby influencing plant growth and changes the demand of nitrate as well as of the other nutrients. Results here reported show a similar pattern for corn salad plants when the temperature of the growing medium has been increased from $15^{\circ} \mathrm{C}$ up to $25^{\circ} \mathrm{C}$. In addition, experimental evidence shows that as the requirements for protein synthesis decrease, so amino acids accumulate and the demand for $\mathrm{NO}_{3}{ }^{-}$falls, but not its uptake, so $\mathrm{NO}_{3}{ }^{-}$accumulates (Lawlor et al., 1987a, 1987b, 1988; Miller et al., 2001).

In summary, results of this study showed that, independently from the effect on nutrient availability, the temperature of the growing medium plays an important role in the functionality of root apparatus of corn salad plants, which in turn can affect their growth and food quality and safety. This aspect is particularly relevant for soilless cultures using hydroponics in which, during summer or early spring, the temperature of the nutrient solution could be too different from that required to optimize plant growth. Because the increase or decrease in temperature above or below the optimum level can alter several physiological functions such as photosynthesis, chlorophyll formation and pigmentation, nutrient uptake, synthesis of secondary metabolites in plants (Nxawe et al., 2010), and, as a consequence, the yield and the establishment of the optimum temperatures in the growing medium to meet demands of specific plant species appear very important particularly in hydroponics in which heating or cooling can be easily provided (Calatayud et al., 2008). In the environmental conditions used in the present work for corn salad plants grown in hydroponics with a floating system, maintaining of the growing medium temperature at a level close to that of air appears to be the most appropriate to maximize the yield, guaranteeing the safety of the edible tissues and their properties fundamental for storing post-harvest. Moreover, the experimental evidence proves that root temperature levels higher than those of shoot (air temperature) for a long span of time are deleterious for root functionality and plant growth.

\section{Literature Cited}

Astolfi, S., S. Zuchi, S. Cesco, L. Sanità di Toppi, D. Pirazzi, and M. Badiani. 2006. Fe deficiency induces sulphate uptake and modulates redistribution of reduced sulphur pool in barley plants. Funct. Plant Biol. 33:1055-1061.

Bassirirad, H. 2000. Kinetics of nutrient uptake by roots: Responses to global change. New Phytol. 147:155-169.

Bonan, G.B. 1992. Soil temperature as an ecological factor in boreal forests, p. 126-143. In: Shugart, H.H., R. Leemans, and G.B. Bonan (eds.). A systems analysis of the Global Boreal Forest. Cambridge University Press, Cambridge, UK.

Bowen, G.D. 1991. Soil temperature, root growth, and plant function, p. 309-330. In: Eshel, A., U. Kafkafi, and Y. Waisel (eds.). Plant roots, the hidden half. Marcel Dekker, New York, NY.

Brecht, J.K., M.E. Saltveit, S.T. Talcott, K.R. Schneider, K. Felkey, and J.A. Bartz. 2004. Fresh-cut vegetables and fruits. Hort. Rev. 30:185-246.

Buckley, T.N. 2008. The role of stomatal acclimation in modelling tree adaptation to high $\mathrm{CO}_{2}$. J. Expt. Bot. 59:1951-1961.

Calatayud, A., E. Gorbe, D. Roca, and P.F. Martínez. 2008. Effects of two nutrient solution temperatures on nitrate uptake, nitrate reductase activity, $\mathrm{NH}_{4}{ }^{+}$concentration and chlorophyll a fluorescence in rose plants. Environ. Exp. Bot. 64:65-74.

Calatayud, A., D.J. Iglesias, M. Talón, and E. Barreno. 2004. Response of spinach leaves (Spinacea oleracea L.) to ozone measured by gas exchange, chlorophyll a fluorescence, antioxidant system, and lipid peroxidation. Photosynthetica 42:23-29.

Cesco, S., M. Nikolic, V. Roemheld, Z. Varanini, and R. Pinton. 2002. Uptake of ${ }^{59} \mathrm{Fe}$ from soluble ${ }^{59} \mathrm{Fe}$-humate complexes by cucumber and barley plants. Plant Soil 241:121-128.

Cesco, S., A.D. Rombolà, M. Tagliavini, Z. Varanini, and R. Pinton. 2006. Phytosiderophores released by graminaceous species promote ${ }^{59} \mathrm{Fe}$ uptake in citrus. Plant Soil 287:223-233.

Clarkson, D.T., M.J. Earnshaw, P.J. White, and H.D. Cooper. 1988. Temperature dependent factors influencing nutrient uptake: An analysis of responses at different levels of organization, p. 281-309. In: Long, S.P. and F.I. Woodward (eds.). Plants and temperature. Vol. 42. Society for Experimental Biology, Cambridge, UK.

Clarkson, D.T., L.H. Jones, and J.V. Purves. 1992. Absorption of nitrate and ammonium ions by Lolium perenne from flowing solution cultures at low room temperatures. Plant Cell Environ. 15:99-106.

Coruzzi, G. and D.R. Bush. 2001. Nitrogen and carbon nutrient and metabolite signaling in plants. Plant Physiol. 125:61-64.

Coruzzi, G.M. and L. Zhou. 2001. Carbon and nitrogen sensing and signaling in plants: Emerging 'matrix effects.' Curr. Opin. Plant Biol. 4: 247-253.

Dong, S., C.F. Scagel, L. Cheng, L.H. Fuchigami, and P. Rygiewicz. 2001. Soil temperature and plant growth stage influence nitrogen uptake and amino acid concentration of apple during early spring growth. Tree Physiol. 21:541-547.

Forbush, B. 1983. Assay of Na,K-ATPase in plasmamembrane preparations-Increasing the permeability of membrane-vesicles using sodium dodecyl-sulphate buffered with bovine serum albumin. Anal. Biochem. 128:159-163.

Gavito, M.E., P.S. Curtis, T.N. Mikkelsen, and I. Jakobsen. 2001. Interactive effects of soil temperature, atmospheric carbon dioxide and soil $\mathrm{N}$ on root development, biomass and nutrient uptake of winter wheat during vegetative growth. J. Expt. Bot. 52:1913-1923.

Graves, W.R., R.J. Joly, and M.N. Dana. 1991. Water use and growth of honey locust and treeof-heaven at high root-zone temperature. HortScience 26:1309-1312.

Hernández-Apaolaza, L. and J.J. Lucena. 2011. Influence of irradiation time and solution concentration on the photochemical degradation of EDDHA/Fe3+: Effect of its photodecomposition products on soybean growth. J. Sci. Food Agr. 91:2024-2030.

Huang, B., X. Liub, and Q. Xub. 2001. Supraoptimal soil temperatures induced oxidative stress in leaves of creeping bentgrass cultivars differing in heat tolerance. Crop Sci. 41:430435.

Huang, B., H.M. Taylor, and B.L. McMichael. 1991. Effects of temperature on the development of metaxylem in primary wheat roots and its hydraulic consequences. Ann. Bot. (Lond.) 67:163-166.

Huang, B. and Q. Xu. 2000. Root growth and nutrient status of creeping bentgrass cultivars differing in heat tolerance as influenced by supraoptimal shoot and root temperatures. J. Plant Nutr. 23:979-990.

Iacuzzo, F., S. Gottardi, N. Tomasi, E. Savoia, R. Tommasi, G. Cortella, R. Terzano, R. Pinton, L. Dalla Costa, and S. Cesco. 2011. Corn salad [Valerianella locusta (L.) Laterr.] growth in a water-saving floating system as affected by iron and sulfate availability. J. Sci. Food Agr. 91:344-354.

Lambers, H. and H. Poorter. 1992. Inherent variation in growth rate between higher plants: A search for physiological causes and ecological consequences. Adv. Ecol. Res 23:187-242.

Lambers, H., R. van den Boogarrd, E.J. Veneklaas, and R. Villar. 1995. Effects of global environmental change on carbon partitioning in vegetative plants of Triticum aestivum and closely related Aegilops species. Glob. Change Biol. 1:397-406.

Landhäusser, S.M., A. DesRochers, and V.J. Lieffers. 2001. A comparison of growth and physiology in Picea glauca and Populus tremuloides at different soil temperatures. Can. J. For. Res. 31:1922-1929. 
Lawlor, D.W. 2002. Carbon and nitrogen assimilation in relation to yield: Mechanisms are the key to understanding production systems. J. Expt. Bot. 53:773-787.

Lawlor, D.W., F.A. Boyle, A.C. Kendall, and A.J. Keys. 1987a. Nitrate nutrition and temperature effects on wheat: Enzyme composition, nitrate and total amino acid content of leaves. J. Expt. Bot. 38:378-392.

Lawlor, D.W., F.A. Boyle, A.J. Keys, A.C. Kendall, and A.T. Young. 1988. Nitrate nutrition and temperature effects on wheat: A synthesis of plant growth and nitrogen uptake in relation to metabolic and physiological processes. J. Expt. Bot. 39:329-343.

Lawlor, D.W., F.A. Boyle, A.T. Young, A.C. Kendall, and A.J. Keys. 1987b. Nitrate nutrition and temperature effects on wheat: Soluble components of leaves and carbon fluxes to amino acids and sucrose. J. Expt. Bot. 38: 1091-1103.

Leuschner, C., G. Moser, C. Bertsch, M. Röderstein, and D. Hertel. 2007. Large altitudinal increase in tree root/shoot ratio in tropical mountain forests of Ecuador. Basic Appl. Ecol. 8:219-230

Manzocco, L., M. Foschia, N. Tomasi, M. Maifreni, L. Dalla Costa, M. Marino, G. Cortella, and S. Cesco. 2011. Influence of hydroponic and soil cultivation on quality and shelf life of ready-to-eat lamb's lettuce (Valerianella locusta L. Laterr). J. Sci. Food Agr. 91:13731380.

Miller, A.J., S.J. Cookson, S.J. Smith, and D.M. Wells. 2001. The use of microelectrodes to investigate compartmentation and the transport of metabolized inorganic ions in plants. J. Expt. Bot. 52:541-549.

Moorby, H. and P.H. Nye. 1984. The effect of temperature variation over the root system on root extension and phosphate uptake by rape. Plant Soil 78:283-293.

Ndakidemi, P.A. and J.M.R. Semoka. 2006. Soil fertility survey in western Usambara
Mountains, northern Tanzania. Pedosphere $16: 237-244$

Nikolic, M., S. Cesco, V. Roemheld, Z. Varanini, and R. Pinton. 2007. Short-term interactions between nitrate and iron nutrition in cucumber. Funct. Plant Biol. 34:402-408.

Nxawe, S., C.P. Laubscher, and P.A. Ndakidemi. 2009. Effect of regulated irrigation water temperature on hydroponics production of Spinach (Spinacia oleracea L). African J. Agr. Res. 4:1442-1446.

Nxawe, S., P.A. Ndakidemi, and C.P. Laubscher. 2010. Possible effects of regulating hydroponic water temperature on plant growth, accumulation of nutrients and other metabolites. Afr. J. Biotechnol. 9:9128-9134.

Pregitzer, K.S. and J.S. King. 2005. Effects of soil temperature on nutrient uptake, p. 277-310. In: Bassiri, H. (ed.). Nutrient acquisition by plants: An ecological perspective. Springer-Verlag, Berlin, Germany.

Pregitzer, K.S., J.S. King, A.J. Burton, and S.E. Brown. 2000. Responses of tree fine roots to temperature. New Phytol. 147:105-115.

Prosser, I.M., J.V. Purves, L.R. Saker, and D.T. Clarkson. 2001. Rapid disruption of nitrogen metabolism and nitrate transport in spinach plants deprived of sulphate. J. Expt. Bot. 52:113-121.

Rodríguez-Lucena, P., N. Tomasi, R. Pinton, L. Hernández-Apaolaza, J.J. Lucena, and S. Cesco. 2009. Evaluation of ${ }^{59} \mathrm{Fe}$-lignosulfonates complexes as Fe-sources for plants. Plant Soil 325: 53-63.

Santamaria, P. 2006. Nitrate in vegetables, toxicity, content, intake and EC regulation. J. Sci. Food Agr. 86:10-17.

Santarius, K.A. 2004. The protective effect of sugars on chloroplast membranes during temperature and water stress and its relationship to frost, desiccation and heat resistance. Planta 113:97-191.

Summerfield, R.J., F.J. Muehlbauer, and R.W. Short. 1989. Controlled environments as an adjunct to field research on Lentils (Lens culinaris). IV. Cultivar responses to aboveand below-average temperatures during vegetative growth. Exp. Agr. 25:119-134.

Thomas, R.B. and B.R. Strain. 1991. Root restriction as a factor in photosynthetic acclimation of cotton seedlings grown in elevated carbon dioxide. Plant Physiol. 96:627-634.

Wang, X.F. and L. Tadashi. 1997. Effect of $\mathrm{NO}_{3}{ }^{-}-$ $\mathrm{N}$ in the additional nutrient solution on the growth, yield, and $\mathrm{NO}_{3}{ }^{-}$content in spinach plant grown in hydroponics. J. Jpn. Soc. Hort. Sci. 66:313-319.

Westwood, M.N. 1988. Temperate-zone pomology. Timber Press, Portland, OR, pp. 140109-128

$\mathrm{Xu}, \mathrm{Q}$. and B. Huang. 2000. Growth and physiological responses of creeping bentgrass to changes in air and soil temperatures. Crop Sci. 40:13631368.

Yamori, W., K. Noguchi, T.K. Hanba, and I. Terashima. 2006. Effects of internal conductance on the temperature dependence of the photosynthetic rate in spinach leaves from contrasting growth temperatures. Plant Cell Physiol. 47:1069-1080.

Yamori, W., K. Noguchi, Y. Kashino, and I. Terashima. 2008. The role of electron transport in determining the temperature dependence of the photosynthetic rate in spinach leaves grown at contrasting temperatures. Plant Cell Physiol. 49:583-591.

Zancan, S., S. Cesco, and R. Ghisi. 2006. Effect of UV-B radiation on iron content and distribution in maize plants. Environ. Exp. Bot. 55: 266-272.

Zhang, S. and Q.L. Dang. 2007. Interactive effects of soil temperature and $\left[\mathrm{CO}_{2}\right]$ on morphological and biomass traits in seedlings of four boreal tree species. For. Sci. 53:453-460.

Zuchi, S., S. Cesco, Z. Varanini, R. Pinton, and S. Astolfi. 2009. Sulphur deprivation limits Fedeficiency responses in tomato plants. Planta 230:85-94. 